\title{
Evaluation of phytoremediation potentials of different plants' varieties in petroleum products polluted soil
}

\author{
Akpokodje O. I. ${ }^{1}$, Uguru H. ${ }^{2 \star}$ and Esegbuyota D. ${ }^{1}$ \\ 1Department of Civil Engineering Technology, Delta State Polytechnic, Ozoro, Nigeria. \\ ${ }^{2}$ Department of Agricultural and Bio-Environmental Engineering Technology, Delta State Polytechnic, Ozoro, Nigeria. \\ *Corresponding author. Email: erobo2011@gmail.com \\ Copyright @ 2019 Akpokodje et al. This article remains permanently open access under the terms of the Creative Commons Attribution License 4.0, \\ which permits unrestricted use, distribution, and reproduction in any medium, provided the original work is properly cited.
}

Received 24th May, 2019; Accepted 14th June 2019

\begin{abstract}
A pot experiment was conducted to evaluate the effect of three groundnut varieties (SAMNUT 10, SAMNUT 11 and SAMNUT 22) and two spinach varieties (African Spinach and Feather Cockscomb) on the Total Hydrocarbon Content (THC) on soil samples. Plastic buckets filled with $10 \mathrm{~kg}$ of topsoil were pounded daily with a mixture of $1 \mathrm{~L}$ of spent engine oil, $1 \mathrm{~L}$ of kerosene, $1 \mathrm{~L}$ of petrol and $1 \mathrm{~L}$ of diesel for ten days, before they were left to stabilize for a period of three weeks. Plant and soil THC analysis were done using standard methods approved by ASTM D 9071B. Test results showed that Arachis hypogaea and spinach plants had significant effect $(p \leq 0.05)$ on the THC of the contaminated soil samples. From the results, Arachis hypogaea was able to degrade the THC from $1024 \mathrm{mg} / \mathrm{kg}$ to $133.31 \mathrm{mg} / \mathrm{kg}$ (about $86 \%$ reduction), while the spinach was able to degrade the THC from $1024 \mathrm{mg} / \mathrm{kg}$ to $192.98 \mathrm{mg} / \mathrm{kg}$ (about $80 \%$ reduction) within the experimental period of 14 weeks. In addition, the results showed presence of THC in the plant (root and leaf), with higher concentration (about $90 \mathrm{mg} / \mathrm{kg}$ for Arachis hypogaea and $72 \mathrm{mg} / \mathrm{kg}$ for spinach) in the roots than in the leaves (about $56 \mathrm{mg} / \mathrm{kg}$ for Arachis hypogaea and $38 \mathrm{mg} / \mathrm{kg}$ for spinach). The results obtained will help to evaluate the use of phytoremediation to clean up soils contaminated with petroleum products.
\end{abstract}

Keywords: Arachis hypogaea, Celosia argentea, phytoremediation, spent engine oil, Total Hydrocarbon Content.

\section{INTRODUCTION}

It was estimated that 116 million metric tons of crude oil was spilled into the environment in 2018 which is the largest recorded in the last 24 years (ITOPF, 2018). The three-major segments of the petroleum industry includes the following, the exploration and production segments which include field works, refining and marketing segment that processes crude oil and gas into marketable products, and the supply infrastructure which is made up of transport structures used to transport crude oil and petroleum product from one locality to the other (Walls, 2010). The presence of crude oil or refined petroleum products in the soil can lead to soil contamination, toxic effects on plants and soil microorganisms, and ground water contamination. Petroleum contamination of soil occurs through extraction, accidents, spillages, consumption and refining process (Scott, 2003). Consequently, the remediation of contaminated soil does not only alleviate environmental problems but it also preserves agricultural productivity and human health (Akpan and Usuah, 2014). The spilled of crude oil or refined petroleum products such as fuel or lube oils contains toxic compounds like, hydrocarbons, nitrogen oxygen compounds, sulphur compounds and heavy metals, which have acute and chronic effects on flora and fauna in the environment (Murakami et al., 2008).

The remediation of crude oil polluted soil is very important, and this could be done using various physical, chemical and biological methods. According to Alkorta and Garbisu, (2001) natural remediation techniques have been developed to provide more environmentally friendly and cost effective cleanup of sites impacted by crude oil spills. Phytoremediation, also referred as botanical bioremediation (Chaney et al., 1997), involves the use of green plants to decontaminate soils, water and air. Phytoremediation makes use of the rhizosphere, or the zone of soil closest 
to and directly influenced by plant roots (Frick et al., 1999). Several other methods are already being used to clean up the contaminated environment, but most of them are very expensive and have negative impacts on the environment. For instance, chemical technologies generate large volumetric sludge and increase the costs (Rakhshaee et al., 2009); chemical and thermal methods are both technically difficult and expensive, and they can degrade the valuable components of the soil (Hinchman et al., 1998). Groundnut (Arachis hypogaea L) is a major leguminous crop cultivated in the arid and semi-arid regions of Nigeria, either grown for its oil, kernel, or the haulms (the vegetative residue). Groundnut grows well in a well-drained, sandy loam soils, with soil a $\mathrm{pH}$ range of 5.8 and 6.2. Groundnut contains high quality edible oil $(50 \%)$, easily digestible protein $(25 \%)$ and carbohydrates (Uguru and Nyorere, 2019; FAO, 1994). African Spinach (Amaranthus hybridus $\mathrm{L}$ ) and feather cockscomb belong to the Amaranthaceae family and have different photosynthetic pathways which allows them to grow during hot periods of year (Chaney, 2019), but do better during the rainy season.

There is a remarked alteration in the physical, chemical and microbiological properties of a soil after contamination with petroleum hydrocarbons (Ekundayo et al., 1989). Oil pollution of soil leads to a buildup of essential (organic $\mathrm{C}$, $\mathrm{P}, \mathrm{Ca}, \mathrm{Mg}$ ) and non-essential ( $\mathrm{Mn}, \mathrm{Pb}, \mathrm{Zn}, \mathrm{Fe}, \mathrm{Co}, \mathrm{Cu})$ elements in soil and their eventual translocation into plant tissues (Vwioko et al., 2006). Some of these metals (Mn, $\mathrm{Pb}, \mathrm{Zn}, \mathrm{Fe}, \mathrm{Ni}$, and $\mathrm{Cu}$ ) are needed in minute concentrations for plant's growth, but at higher concentrations, they become hazardous to the plant's growth. Plants respond to environmental pollution differently. Some are more tolerant to toxic substances than others, metals such as arsenic, cadmium, nickel, mercury, chromium, cobalt and selenium are highly toxic even in minute quantities (Salomons et al., 1995; Masindi and Muedi, 2018). The interactions between the root system of higher plants are not only with the soil environment but also with the different communities of metabolically effective microorganisms. The living plants create a special habitat on and around their roots where the microbial population is considerably more than that in root free soil environment ( $\mathrm{Lu}$ et al., 2010). Some plants can hyperaccumulate toxic heavy metals in their tissues (Ndimele, 2003; Ndimele, 2010). Others can convert the pollutants to less toxic compounds and volatilize them (Terry and Zayed, 1994; Brooks, 1998).

Anoliefo and Vwioko (1995) reported that pepper (Capsicum annum L.) responds better in soils contaminated with spent engine oil than tomato (Lycopersicom esculentum). Mirabilis jalapa L successfully remediates crude oil contaminated soil, as it was able to reduce the petroleum hydrocarbons (TPHs) content in contaminated soil up to 41.61 to $63.20 \%$ in a 127 -day culture period (Peng et al., 2009). Yateem et al. (2000) investigated the degradation of total petroleum hydrocarbons (TPH) in the rhizosphere and non- rhizosphere soil of three domestic plants namely, alfalfa (Medicago sativa), broad bean (Vicia faba) and rayegrass (Lolium perenne), and reported the degradation of TPH was more profound in the leguminous plants (Ndimele, 2010). The objectives of this research were to: (i) investigate and provide preliminary evaluation of the effectiveness of different crop varieties Arachis hypogaea L (SAMNUT 10, SAMNUT 11, SAMNUT 22), Amaranthus hybridus and Celosia argentea in the remediation of petroleum products contaminated soils; (ii) evaluate the level of THC in the different plant's parts (i.e. the roots and leaves).

\section{MATERIALS AND METHODS}

\section{Source of material}

The spent engine oil was obtained from a mechanic workshop located at Ozoro, Delta State, Nigeria; while the petrol, diesel and kerosene were obtained from a filling station located at Ozoro, Delta State, Nigeria. The top soil was dug $(0-6 \mathrm{~cm})$, from the Research Station of the Delta State Polytechnic, Ozoro, Nigeria. The plant varieties of interest (Arachis hypogaea L, Amaranthus hybridus, and Celosia argentea) and perforated plastic buckets were obtained from the Department of Agricultural and Bioenvironmental Engineering Technology, Delta State Polytechnic, Ozoro, Nigeria. The research was carried out at the Research Station of the Delta State Polytechnic, Ozoro, Nigeria.

\section{Soil sample preparation}

The collected topsoil was air dried for two weeks in the laboratory and sieved with $2 \mathrm{~mm}$ stainless steel sieve. Plastic buckets were filled with $10 \mathrm{~kg}$ of the sieved soil and divided into two lots. One lot was pounded with $1 \mathrm{~L}$ of spent engine oil, $1 \mathrm{~L}$ of kerosene, $1 \mathrm{~L}$ of petrol and $1 \mathrm{~L}$ of diesel daily for ten days and left to stabilize for three weeks; while the other lot was left uncontaminated, which served as the control.

At the end of the experimental period (14 weeks), soil samples were dug $(25 \mathrm{~cm})$ randomly using a glass tube. This depth is considered as the effective root zone of the plants propagated. Soils samples collected were labeled and air-dried in the laboratory for two weeks

\section{Soil analysis}

Soil analysis was done on the uncontaminated and contaminated (after stabilization period) soil samples to determine the level of some heavy metals and other soil physicochemical parameters present in the soil. All the parameters analyzed (soil pH, electrical conductivity, iron, copper and lead) were determined as per the standard methods (APHA, 1995; Akpokodje et al., 2018). Results of the soil analysis are presented in Table 1. 
Table 1. Physico-chemical properties THC of the soil samples.

\begin{tabular}{lcc}
\hline Parameters & Level before contamination & Level after contamination \\
\hline Physiochemical analysis & & \\
Soil pH $\left(\mathrm{H}_{2} \mathrm{O}\right)$ & 7.75 & 5.90 \\
Soil Electrical conductivity $(\mu \mathrm{S} / \mathrm{cm})$ & 6.224 & 20.91 \\
& & \\
Heavy metals & & \\
Copper $(\mathrm{mg} / \mathrm{kg})$ & 4.892 & 7.729 \\
Lead $(\mathrm{mg} / \mathrm{kg})$ & $<0.001$ & 1.128 \\
Iron $(\mathrm{mg} / \mathrm{kg})$ & 1451.2 & 1587.9 \\
THC & & \\
Soil sample $(\mathrm{mg} / \mathrm{kg})$ & 0.421 & 1024 \\
\hline
\end{tabular}

\section{Determination of Total Hydrocarbon Content (THC)}

The total hydrocarbon content (THC) in the soil samples were determined using the standard method recommended by ASTM D 9071B - 7, as described by Akpan and Usuah (2014). In addition, the residual total hydrocarbon content in the plants' parts (leaves and roots) were quantified by using the standard method of the American Petroleum Institute (API, 1980). Results of the soil THC analysis are presented in Table 1.

\section{Phytoremediation set up}

Twenty five perforated plastic buckets filled with $10 \mathrm{~kg}$ of the contaminated soil, were arranged (five per row) under a shade made from oil palm tree fronds, and clearly labeled in the manner showed in Table 2. The experiment was done under the shady environment to minimize excessive evapotranspiration and the effects of heavy downpour, during the experimental period.

Germination test of the seeds was carried out before planting according to the approach adapted by Agboola (1998) to determine the seeds' viability. Ten plant seeds of the same variety were planted in each bucket. Before planting, $200 \mathrm{~g}$ compost manure (made from green leaves, cattle dungs and poultry droppings) mixed with $100 \mathrm{~g}$ of loamy soil was placed on top of all the buckets, where the seeds were to be placed, to encourage early establishment of the seedlings. All the plants were closely monitored for the 14 week experimental period. Systemic pesticide application was made at the 5th and 9th weeks after germination to prevent insects and pests attacks. Weeding was done by hand picking; while each bucket was watered with $1 \mathrm{~L}$ of tap water when necessary to prevent withering of the plants. In the same vein, the same plants varieties were planted under the control condition, and given the same treatment (pesticide application, weeding and watering).
Table 2. Phytoremediation set up.

\begin{tabular}{ll}
\hline Row & Plant variety \\
\hline Row 1 & Arachis hypogaea L, SAMNUT 10 \\
Row 2 & Arachis hypogaea L, SAMNUT 11 \\
Row 3 & Arachis hypogaea L, SAMNUT 22 \\
Row 4 & Amaranthus hybridus L, African spinach \\
Row 5 & Celosia argentea L, feather cockscomb \\
\hline
\end{tabular}

\section{Statistical analysis}

The relationship between the THC concentrations in the studied soil samples was determined using SPSS statistical software (version 20.0, SPSS Inc, Chicago, IL). The mean was separated using Duncan's Multiple Range Tests at $95 \%$ confidence level. All the experiments were replicated five times, and the average values recorded.

\section{RESULTS AND DISCUSSION}

As shown in Tables 1 and 4 , the average THC concentration of the soil samples drastically increased to $1024 \mathrm{mg} / \mathrm{kg}$ after contamination from an initial average value of $0.421 \mathrm{mg} / \mathrm{kg}$ for the uncontaminated soil samples. The analysis of variance (ANOVA) result presented in Table 3 showed that all the plants varieties had significant $(p \leq 0.05)$ effect on the THC present in the soil. From the separated mean results presented in Table 4 , it can be seen that both groundnut and spinach varieties significantly degraded the THC in the soil within the 14 week experimental period.

The residual THC of the remediated soil samples shows that Arachis hypogaea L. (SAMNUT 10) treated soil had a residual THC of $133.31 \mathrm{mg} / \mathrm{kg}$ (87\% reduction), Arachis hypogaea L. (SAMNUT 11) treated soil had a residual THC of $149.09 \mathrm{mg} / \mathrm{kg}$ ( $86 \%$ reduction), while Arachis hypogaea L. (SAMNUT 22) treated soil had a residual THC of 152.66 
Table 3. The ANOVA of phytoremediation of contaminated soil sample.

\begin{tabular}{lcccc}
\hline Source of variation & df & Soil & Leaves & Roots \\
\hline Material & 4 & $1.21 \mathrm{E}-15^{\star}$ & $1.09 \mathrm{E}-06^{*}$ & $1.04 \mathrm{E}-07^{\star}$ \\
Period & 1 & $7.75 \mathrm{E}-23^{*}$ & $1.59 \mathrm{E}-21^{*}$ & $2.78 \mathrm{E}-21^{*}$ \\
Material x Period & 4 & $0.99926^{\text {ns }}$ & $4.59 \mathrm{E}-07^{*}$ & $4.23 \mathrm{E}-08^{*}$ \\
\hline
\end{tabular}

*Significant at $p \leq 0.05$; ns non-significant.

Table 4. Total THC in soil and plant parts samples after remediation.

\begin{tabular}{lccc}
\hline \multirow{2}{*}{ Crop } & \multicolumn{3}{c}{ Soil sample $(\mathbf{m g} / \mathbf{k g})$} \\
\cline { 2 - 4 } & Uncontaminated soil & Contaminated soil & After 14 weeks remediation \\
\hline SAMNUT 10 & $0.421^{\mathrm{c}} \pm 0.095$ & $1024^{\mathrm{a}} \pm 119.03$ & $133.31^{\mathrm{b}} \pm 1.63$ \\
SAMNUT 11 & $0.421^{\mathrm{c}} \pm 0.095$ & $1024^{\mathrm{a}} \pm 119.03$ & $149.09^{\mathrm{b}} \pm 1.20$ \\
SAMNUT 22 & $0.421^{\mathrm{c}} \pm 0.095$ & $1024^{\mathrm{a}} \pm 119.03$ & $152.65^{\mathrm{b}} \pm 1.63$ \\
African Spinach & $0.421^{\mathrm{c}} \pm 0.095$ & $1024^{\mathrm{a}} \pm 119.03$ & $192.98^{\mathrm{b}} \pm 1.25$ \\
Feather Cockscomb & $0.421^{\mathrm{c}} \pm 0.095$ & $1024^{\mathrm{a}} \pm 119.03$ & $206.31^{\mathrm{b}} \pm 9.25$ \\
\hline
\end{tabular}

Values are mean \pm standard deviation; Columns with the same common letter superscript are not significantly different at ( $p \leq 0.05)$.

Table 5. Total THC in soil and plant parts samples after remediation.

\begin{tabular}{lcccc}
\hline \multirow{2}{*}{ Crop } & \multicolumn{2}{c}{ Roots (mg/kg) } & \multicolumn{2}{c}{ Leaves (mg/kg) } \\
\cline { 2 - 5 } & $\begin{array}{c}\text { Uncontaminated } \\
\text { soil }\end{array}$ & $\begin{array}{c}\text { Contaminated soil (After } \\
\text { 14 weeks remediation) }\end{array}$ & $\begin{array}{c}\text { Uncontaminated } \\
\text { soil }\end{array}$ & $\begin{array}{c}\text { Contaminated soil (After } \\
\text { 14 weeks remediation) }\end{array}$ \\
\hline SAMNUT 10 & $0.196 \pm 0.033$ & $96.78^{\mathrm{d}} \pm 4.41$ & $0.126 \pm 0.009$ & $58.56^{\mathrm{d}} \pm 2.84$ \\
SAMNUT 11 & $0.181 \pm 0.041$ & $87.44^{\mathrm{c}} \pm 7.49$ & $0.121 \pm 0.013$ & $52.86^{\mathrm{c}} \pm 5.30$ \\
SAMNUT 22 & $0.148 \pm 0.023$ & $83.78^{\mathrm{cd}} \pm 3.12$ & $0.117 \pm 0.008$ & $58.56^{\mathrm{cd} \pm 1.21}$ \\
African Spinach & $0.132 \pm 0.021$ & $66.11^{\mathrm{b}} \pm 1.49$ & $0.106 \pm 0.009$ & $35.89^{\mathrm{b}} \pm 6.17$ \\
Feather Cockscomb & $0.137 \pm 0.021$ & $77.44^{\mathrm{b}} \pm 10.53$ & $0.111 \pm 0.014$ & $39.56^{\mathrm{b}} \pm 1.21$ \\
\hline
\end{tabular}

Values are mean \pm standard deviation; Columns with the same common letter superscript are not significantly different at ( $p \leq 0.05$ ).

$\mathrm{mg} / \mathrm{kg}$ (85\% reduction). The Amaranthus hybridus L., African spinach treated soil had a residual THC of 192.98 $\mathrm{mg} / \mathrm{kg}$ ( $81 \%$ reduction), and the Celosia argentea L., feather cockscomb had a residual THC of $206.31 \mathrm{mg} / \mathrm{kg}$ (79\% reduction). Generally, it could be seen that the Arachis hypogaea $\mathrm{L}$ had more remediation potentials than the Celosia argentea L. and the Amaranthus hybridus L. This could be attributed to the nitrogen added to the soil by the nitrogen fixing bacteria found in the roots of the groundnut plants, higher vegetative cover which encouraged the performance of soil micro and macroorganisms and higher leaves droppings which aids the natural biological process within the soil. In addition, the results further depicted that the Arachis hypogaea $\mathrm{L}$. (SAMNUT 10) had the highest capability of remedying the contaminated soil ( $87 \%$ reduction); this could be attributed to its good vegetative cover and root network system. According to Kumar et al. (1995), the ideal plant for phytoremediation should grow rapidly, produce high biomass amount, and should be able to tolerate and accumulate high concentrations of metals in shoots
(Kumar et al., 1995). Edwin-wosu and Kinako (2005) stated that leaves droppings, adequate aeration and nodulation by the plant roots help in mitigating the impact of oil contamination in soils.

Results of the research on residual THC in the plant parts (roots and leaves) after the remediation, showed significant levels in the plants' parts (Table 5), and the concentration varied among the plant parts considered. As shown in Table 5, the residual THC was higher in the plants' roots than in the leaves. From the results, residual THC in the root of Arachis hypogaea L (SAMNUT 10) was found to be $96.78 \mathrm{mg} / \mathrm{kg}$ as against $0.196 \mathrm{mg} / \mathrm{kg}$ recorded for the SAMNUT 10; Arachis hypogaea L (SAMNUT 11) roots had residual THC of $87.44 \mathrm{mg} / \mathrm{kg}$; and Arachis hypogaea L (SAMNUT 12) roots had residual THC of $83.78 \mathrm{mg} / \mathrm{kg}$. The African spinach had a residual THC of $66.11 \mathrm{~b} \mathrm{mg} / \mathrm{kg}$, and the Celosia argentea L (feather cockscomb) had a residual THC of $206.377 .44 \mathrm{mg} / \mathrm{kg}$. Also, as can be seen from the experimental results, the residual THC in the Arachis hypogaea L. leaves was higher than the concentrations found in their Celosia 
argentea L. counterparts. Residual THC of $58.56,52.86$ and $58.56 \mathrm{mg} / \mathrm{kg}$ was found in the leaves of SAMNUT 10 , SAMNUT 11 and SAMNUT 22 respectively; while the leaves of African spinach and feather cockscomb recorded residual THC of 35.89 and $39.56 \mathrm{mg} / \mathrm{kg}$ respectively. According to Newman and Reynoids (2004) and Wenzel (2009) plants roots help to provide an ideal environment for degradation of toxic compounds, as they allow rapid movement of water and gases through the soil, and provide a biologically active soil region, which encourages microbial activity and enhances bioavailability. Similar results were reported by Akpan and Usuah (2014) in which diesel oil contaminated soil had a negative effect on fluted pumpkin (Telfairia occidentalis Hook F.) during the first four weeks of planting. Dominguez-Rosado and Pichtel (2004) studied the remediation of spent engine oil, using soybean (Glycine max), green bean (Phaseolus vulgaris), sunflower (Helianthus annuus), Indian mustard (Brassica juncea), maize (Zea mays) and mixed clover (Trifoleum partense, L. Trifoleum repense), and reported about $99 \%$ reduction of the contaminants after 150 days. In the study of Anyasi and Atagana (2017) on the phytoremediation of crude oil contaminated site, they reported that, C. odorata, A. Africanus, C. ciliate, C. bipinatus, P. vaginatum, C. babata, E. atrovirens, B. acuminate, U. chamae, were able to remediate the site to a significant level; and in a related development, the $C$. odorata, B. acuminate and U. chamae demonstrated the ability to grow at the highest $\mathrm{TPH}$ contaminated condition which according to the site ranges from 329 to $214,241,373$ to 8011,274 to $6318 \mathrm{mg} / \mathrm{kg}$ respectively. In addition, Alexander (1994) and Walworth et al. (1997) stated that soil microorganisms require macronutrients (mostly nitrogen) in higher concentration and also micronutrients to degrade crude oil contaminated soil; and for successful phytoremediation both plants and microbes must survive and grow in the contaminated soil (White et al., 2006).

Plant selection is an important factor to be considered for successful phytoremediation of contaminated soil, and the five plants used in this study showed high phytoremediation potentials. Karenlampi et al. (2000) stated that the four major characteristics make a plant suitable for phytoremediation are: the plant's ability to accumulate extracted pollutant; plants should have enough tolerance to be able to not only survive in polluted soils; but to carry pollutants within their stems; the species should be fast growing with an amplified ability to accumulate toxins; the plant should be easily harvestable for simple disposal (Balqees et al., 2016). According to Ndimele (2010), several species of plant have been shown to have the ability to grow in contaminated soils and actually extract the pollutant from the growth medium, such plants could solely do this or in conjunction with microorganisms. The uniqueness of the green vegetable in phytoremediation stem from the fact that it has a fibrous root network that increases their surface area in contact with the pollutant.

\section{Conclusion}

This research was carried out to evaluate the effect of different plants varieties in remediating petroleum products contaminated soils. The results obtained from the research showed that groundnut, a leguminous crop, was found to remediate better than the spinach vegetables. The THC in the contaminated soil was degraded by about $88 \%$ by the groundnut varieties; and by about $82 \%$ by the spinach varieties within the 14 weeks remediation period. In respect to the plant parts (roots and leaves), presence of hydrocarbon was found in them; higher in the roots than in the leaves. From the results, it can be concluded that plant selection is an important factor to be considered for successful phytoremediation of contaminated soil. Therefore, more plants varieties should be researched on to determine their efficacy and potentials.

\section{CONFLICT OF INTEREST}

The authors declare that they have no conflict of interest.

\section{REFERENCES}

Agboola, D. A. (1998). Dormancy and seed germination in some weeds of tropical waste lands. Nigerian Journals Botany, 11, 79-87.

Akpan, G. U., \& Usuah, P. E. (2014). Phytoremediation of Diesel Oil Polluted Soil by Fluted Pumpkin (Telfairia Occidentalis Hook F.) in Uyo, Niger Delta Region, Nigeria. Journal of Environment and Earth Science, 4(1), 6-15.

Akpokodje, O. I., Uguru, H., \& Esegbuyota, D. (2018). Remediation of cassava effluent contaminated soil using organic soap solution: case study of soil physical properties and plant growth performance. Journal of Scientific Research and Reports, 21(3), 1-11.

Alexander, M. (1994). Biodegradation and bioremediation. Academic Press, Inc., San Diego, CA.

Alkorta, I., \& Garbisu, C. (2001). Phytoremediation of organic contaminants in soils. Bioresources and Technology, 79(3), 273-276.

American Public Health Association (APHA) (1995). Standard Methods for Examination of Water and Wastewater; 16th Edition, Washington DC.

Anoliefo, G. O., \& Vwioko, D. E. (1995). Effects of spent lubricating oil on the growth of Capsicum annum L. and Lycopersicon esculentum Miller. Environmental Pollution, 88(3), 361-364.

Anyasi, R. O., \& Atagana, H. I. (2017). Assessment of Plants at Petroleum Contaminated Site for Phytoremediation. Proceedings of the International Conference of Recent Trends in Environmental Science and Engineering (RTESE'17) Toronto, Canada - August 23 - 25, 2017 Paper No. 105 DOI: 10.11159/rtese17.105.

API (1980). Manual on disposal of petroleum wastes. American Petroleum Institute, Washington D. C.

ASTM D 9071B - 7. Hexane Extractable Materials using Soxhlet Extraction Method, American Society for Testing and Materials Balqees, S. A., Haleemah, J. A., Dhafar, Dh. A., \& Hamid, T. A. 
(2016). Petroleum hydrocarbons in water, soil and tomato plant (Lycopersican esculentum L.) at Basra City, Iraq. Journal of Biology, Agriculture and Healthcare, 6(12), 54-64

Brooks, R. R. (1998). Phytoremediation by Volatilization. In: Plants that Hyperaccumulate Heavy metals: Their Roles in Phytoremediation, Microbiology, Archaeology, Mineral Exploration and Phytomining, Brooks, R.R. (Ed.). CAB International, Oxon, UK., Pp. 289-312.

Chaney, C. (2019). How to Grow African Spinach. Home Guides | SF Gate, Available at http://homeguides.sfgate.com/growafrican-spinach-68403.html. Accessed 22 May 2019.

Chaney, R. L., Malik, M., Li, Y. M., Brown, S. L., Brewer, E. P., Angle, J. S., \& Baker, A. J. (1997). Phytoremediation of soil metals. Current Opinion in Biotechnology, 8(3), 279-284.

Dominguez-Rosado, E., \& Pichtel, J. (2004). Phytoremediation of soil contaminated with used motor oil: II. Greenhouse studies. Environmental Engineering Science, 21(2), 169-180.

Edwin-wosu, N. L. \& Kinako, P. D. S (2005). Phytoremediation (series 2): A short-term comparative analysis of enhanced biodegradation of crude oil in the soil by macrophytic nodulation. Global Journal Environmental Science, 4(1), 1118.

Ekundayo, J. A., Aisueni, N. \& Benka-Coker, M. O. (1989). The effects of drilling fluids in some waste and burrow pits in western operational areas of Shell Petroleum Development Company of Nigeria Limited on the soil and water quality of the areas. Environmental Consultancy Service Group, Consultancy Services Unit, University of Benin, Benin City, Nigeria.

FAO (1994). Expert's recommendations on fats and oils in human nutrition. The article is adapted from the first chapter of fats and oils in human nutrition: report of joint expert consultation, FAO Food and Nutrition Paper No. 57.

Frankenberger, W. T. (1988). Use of urea as a nitrogen fertilizer in bioreclamation of petroleum hydrocarbons in soil. Bulletin of Environmental Contamination and Toxicology, 40(1), 66-68.

Frick, C. M., Germida, J. J., \& Farrell, R. E. (1999). Assessment of phytoremediation as an in-situ technique for cleaning oilcontaminated sites. In technical seminar on chemical spills (pp. 105a-124a). Environment Canada; 1998.

Hinchman, R. R., Negri, M. C., \& Gatliff, E. G. (1998). Phytoremediation: using green plants to clean up contaminated soil, groundwater, and wastewater, Argonne National Laboratory Hinchman, Applied Natural Sciences, Inc, $1995 . \quad$ Available at http://www.treemediation.com/Technical/Phytoremediation 1998.pdf.

ITOPF (2018). Oil Tanker Spill Statistics 2018. Available at https://www.itopf.org/knowledge-resources/datastatistics/statistics/

Kärenlampi, S., Schat, H., Vangronsveld, J., Verkleij, J. A. C., van der Lelie, D., Mergeay, M., \& Tervahauta, A. I. (2000). Genetic engineering in the improvement of plants for phytoremediation of metal polluted soils. Environmental Pollution, 107(2), 225231.

Kumar, P. N., Dushenkov, V., Motto, H., \& Raskin, I. (1995). Phytoextraction: the use of plants to remove heavy metals from soils. Environmental Science \& Technology, 29(5), 12321238.

Lu, M., Zhang, Z., Sun, S., Wei, X., Wang, Q., \& Su, Y. (2010). The use of goosegrass (Eleusine indica) to remediate soil contaminated with petroleum. Water, Air, and Soil Pollution, 209(1-4), 181-189.

Masindi, V., \& Muedi, K. L. (2018). Environmental Contamination by Heavy Metals. In Heavy Metals. Saleh, H. E-D. M., \& Aglan,R. F. (eds.), IntechOpen. Available at https://www.intechopen.com/books/heavy-

metals/environmental-contamination-by-heavy-metals. Accessed May 19, 2019.

Murakami, Y., Kitamura, S. I., Nakayama, K., Matsuoka, S., \& Sakaguchi, H. (2008). Effects of heavy oil in the developing spotted halibut, Verasper variegatus. Marine Pollution Bulletin, 57(6), 524-528.

Ndimele, P. E. (2003). The prospect of phytoremediation of polluted natural wetlands by inhabiting aquatic macrophytes (Water hyacinth). M.Sc. Thesis, University of Ibadan, Nigeria.

Ndimele, P. E. (2010). A review on the phytoremediation of petroleum hydrocarbon. Pakistan Journal of Biological Sciences, 13(15), 715.

Newman, L. A., \& Reynolds, C. M. (2004). Phytodegradation of organic compounds. Current Opinion in Biotechnology, 15(3), 225-230.

Peng, S., Zhou, Q., Cai, Z., \& Zhang, Z. (2009). Phytoremediation of petroleum contaminated soils by Mirabilis jalapa $\mathrm{L}$. in a greenhouse plot experiment. Journal of Hazardous Materials, 168(2), 1490-1496.

Rakhshaee, R., Giahi, M., \& Pourahmad, A. (2009). Studying effect of cell wall's carboxyl-carboxylate ratio change of Lemna minor to remove heavy metals from aqueous solution. Journal of Hazardous Materials, 163(1), 165-173.

Salomons, W., Forstner, U., \& Mader, P. (1995). Heavy Metals: Problems and Solutions. Berlin, Germany: Springer-Verlag.

Scott, S. L. (2003). Biodegradion and Toxicity of Total Petroleum Hydrocarbon Leachate from Land Treatment Units. Department of Engineering, California Polytechnic State University, 52.

Terry, N., \& Zayed, A.M. (1994). Selenium Volatilization by Plants. In: Selenium in the Environment, Frankenberger, W. T., \& Benson, S. (Eds.). Marcel Dekker, New York, Pp. 343-369.

Uguru, H., \& Nyorere, O. (2019). Failure behaviour of groundnut (samnut 11) kernel as affected by kernel size, loading rate and loading position. International Journal of Scientific \& Engineering Research, 10(2), 1209-1217.

Vwioko, D. E., Anoliefo, G. O., \& Fashemi, S. D. (2006). Metal concentration in plant tissues of Ricinus communis L. (castor oil) grown in soil contaminated with spent lubricating oil. Journal of Applied Sciences and Environmental Management, 10(3), 127-134.

Walls, W. D. (2010). Petroleum refining industry in China. Energy Policy, 38(5), 2110-2115.

Walworth, J. L., Woolard, C. R., Braddock, J. F., \& Reynolds, C. M. (1997). Enhancement and inhibition of soil petroleum biodegradation through the use of fertilizer nitrogen: an approach to determining optimum levels. Soil and Sediment Contamination, 6(5), 465-480.

Wenzel, W. W. (2009). Rhizosphere processes and management in plant-assisted bioremediation (phytoremediation) of soils. Plant and Soil, 321(1-2), 385-408.

White, P. M., Wolf, D. C., Thoma, G. J., \& Reynolds, C. M. (2006). Phytoremediation of alkylated polycyclic aromatic hydrocarbons in a crude oil-contaminated soil. Water, Air, and Soil Pollution, 169(1-4), 207-220.

Yateem, A., Balba, M.T. El-Nawawy, A.S. \& Al-Awadhi, N. (2000). Plants-associated Microflora and the remediation of oil contaminated soil. International Journal of Phytoremediation, 2(3), 183-191. 